\title{
The effect of audit quality on the performance of listed companies in Tehran Stock Exchange
}

\author{
Morteza Ziaee \\ Department of Management, Ghorveh Branch, Islamic Azad University, Ghorveh, Iran \\ E-mail address: morteza_ziaee@yahoo.com
}

\begin{abstract}
Audit opinion shopping has been studied extensively in accounting research. A firm engages in opinion shopping by influencing or even manipulating its auditor's decision in certain ways to obtain an opinion that is more favorable that that warranted by the quality of its accounting information. If such behavior exists, then it would lead to a higher degree of information asymmetry between managers and investors and weaken auditing's protective effect on investors. Many researches have been done to improve the understanding of audit quality to a better understanding This concept can be achieved and the relationship between audit quality and other parameters to be determined. One of Many variables that its relationship with audit quality research, examined. The size of the audit firm. Methods of the research in this field Angelou January 1981 to practice. He stated his Yhay concluded between audit quality and auditor size. There is a positive relationship. This study sought to examine the relationship between audit quality and financial performance of companies in Iran. For this population the financial manager is accepted in Tehran Stock Exchange and 2008 to 2012 have been selected. Distribute and collect the questionnaires they reached the conclusion that audit quality could affect the financial performance of companies.
\end{abstract}

Keywords: audit; audit quality; performance; Tehran Stock Exchange

\section{INTRODUCTION}

The Sarbanes-Oxley Act (hereafter SOX) of 2002 went into effect on July 30, 2002 to address the increasing concern of investors about the integrity of firms' financial reporting, due to scandals involving once well-respected companies,such as Enron and WorldCom and auditors, such as Arthur Andersen.One important aspect of SOX is that it has two sections specifically focusing on internal control issues related to financial reporting. Under Section 302 , management is required to disclose all material weaknesses in internal control, when they certify the periodic, annual and quarterly, statutory financial reports. Under Section 404, a firm is required to assess the effectiveness of its internal control structure and procedures for financial reporting and disclose such information in its annual reports. Furthermore, the firm's auditor is required to provide an opinion on the assessment made by the management in the same report. Because such mandatory disclosure under SOX provides us with more information on internal controls, we are interested in investigating the determinants of internal control weaknesses in the post-SOX era. We begin with a sample of firms with internal control weaknesses, and based on industry, size, and performance, match these firms to a sample of 
control firms without internal control weaknesses. Our conditional logit analyses indicate that a relation exists between audit committee quality, auditor independence, and internal control weaknesses. Firms are more likely to be identified with an internal control weakness, if their audit committees have less financial expertise or, more specifically, have less accounting financial expertise and non-accounting financial expertise.

They are also more likely to be identified with an internal control weakness, if their auditors are more independent. In addition, firms with recent auditor changes are more likely to have internal control weaknesses. Our paper is related to several recent papers on the determinants of internal control weaknesses. Krishnan (2005) examines the period prior to the enactment of SOX, when internal control problems are only disclosed in 8-Ks filed by firms when changing auditors. With information collected from $8-\mathrm{K}$ filings, she finds that independent audit committees and audit committees with more financial expertise are significantly less likely to be associated with the incidence of internal control problems. Ge and McVay (2005) and Doyle et al. (forthcoming) find that material weaknesses in internal control are more likely for firms that are smaller, less profitable, more complex, growing rapidly, or undergoing restructuring. Ashbaugh-Skaife et al. (forthcoming) find that firms with more complex operations, recent changes in organization structure, auditor resignation in the previous year, more accounting risk exposure, and less investment in internal control systems are more likely to disclose internal control deficiencies.

\section{BACKGROUND}

SOX emphasizes internal control, which is defined as "a process, effected by an entity's board of directors, management and other personnel, designed to provide reasonable assurance regarding the achievement of objectives according to the COSO framework.1 SOX Section 302 (hereafter SOX 302), which went into effect on August 29, 2002, requires management to disclose significant internal control deficiencies, when they certify annual or quarterly financial statements. Specifically, the signing officers, being responsible for internal controls, have evaluated the internal controls within the previous ninety days and reported in their findings: (1) a list of all deficiencies in the internal controls and information on any fraud that involves employees who are involved with internal control activities; (2) any significant changes in internal controls or related factors that could have a negative impact on the internal controls.

\section{1. Audit committee quality and internal control}

Since an entity's internal control is under the purview of its audit committee (Krishnan, 2005), we investigate the relation between audit committee quality and internal control weaknesses. The audit committee not only plays an important monitoring role to assure the quality of financial reporting and corporate accountability (Carcello and Neal, 2000), but also serves as an important governance mechanism, because the potential litigation risk and reputation impairment faced by audit committee members ensure that these audit committee members discharge their responsibilities effectively. We thus expect that firms with highquality audit committees are less likely to have internal control weaknesses than firms with low-quality audit committees. On measuring audit committee quality, we focus on the financial expertise in these committees. The Blue Ribbon Committee on Improving the Effectiveness of Corporate Audit Committees (BRC)'s (1999) recommendation that each audit committee should have at least one financial expert highlights the importance of the financial literacy and expertise of audit committee members.5 Section 407 of the SOX incorporates the above 
suggestion and requires firms to disclose in periodic reports, whether a financial expert serves on a firm's audit committee and, if not, why not. Such financial expertise of audit committee members has been shown to be important for dealing with the complexities of financial reporting (Kalbers and Fogarty, 1993) and for reducing the occurrence of financial restatements (Abbott et al., 2004). In addition, DeZoort and Salterio (2001) find that audit committee members with financial reporting and auditing knowledge are more likely to understand auditor judgments and support the auditor in auditor-management disputes than members without such knowledge. Moreover, financially knowledgeable members are more likely to address and detect material misstatements. Audit committee members with financial expertise can also perform their oversight roles in the financial reporting process more effectively, such as detecting material misstatements (Scarbrough et al., 1998; Raghunandan et al., 2001). Indeed, Abbott et al. (2004) find a significantly negative association between an audit committee having at least one member with financial expertise and the incidence of financial restatement. Krishnan (2005) presents evidence that audit committees with financial expertise are less likely to be associated with the incidence of internal control problems. Therefore, we have the following directional prediction.

\section{2. Audit committee characteristics and quality of earnings}

A firm's audit committee primarily oversees the financial reporting process of a firm. It meets regularly with the outside auditors and internal financial managers of the firm to review the financial statements, audit process, and internal accounting controls of the firm. Thus, audit committees potentially serve an important oversight role and can affect the quality of reported earnings. Supporting this view, McMullen (1996) finds that firms with well-established audit committees are more likely to have reliable financial reporting (i.e., the absence of errors, irregularities, or illegal acts). Two characteristics of audit committees appear to be of particular importance when measuring effectiveness within the U.S.: audit committee independence and financial sophistication. Several studies suggest that more independent audit committees are more effective. For example, Klein (2002) documents a negative relationship between audit committee independence and abnormal accruals. Carcello and Neal (2003) report that distressed firms that have more independent audit committees are

less likely to be issued going-concern reports by their auditors, and more independent audit committees are more effective in shielding auditors from dismissal when a new going-concern report is issued. Chen and Zhou (2007) find that more independent audit committees were quicker to dismiss Arthur Andersen as their firm's auditor after Andersen's credibility was threatened around the Enron scandal. Krishnan (2005) finds that independent audit committees are significantly less likely to be associated with incidences of internal control problems. However, recent reforms in the U.S. have dictated that firms have some committees, including the audit committee, be comprised entirely of outside directors. An argument for complete independence is that it provides independent committee members an opportunity to talk outside of management's hearing, and thus, reduces management's influence over the committee. Consistent with this view, the results in Shivdasani and Yermack (1999) suggest that CEOs do not exert as much control over the director selection process when they do not serve on the nominating committee. Similarly, Anderson et al. (2004) find that fully independent audit committees are associated with a significantly lower cost of debt, suggesting more reliable financial reporting in these firms. DeFond et al. (2005) state that one of the most controversial provisions of Sarbanes-Oxley requires public companies in the U.S. to disclose whether they have a financial expert on their audit committee. The argument is that financial expertise is necessary to ensure that audit committees fulfill their primary responsibilities of overseeing the 
financial reporting process and ensuring high-quality financial reporting.Numerous studies provide support for this view. For instance, DeFond et al. (2005) find a positive stock market reaction to the appointment of an accounting financial expert to the audit committee. Similarly, Davidson et al. (2004) find a significantly positive stock price reaction when new members of audit committees have financial expertise. Xie et al. (2003) find the financial sophistication of audit committee members appears to be an important factor in constraining the propensity of managers to engage in earnings management.

Agrawal and Chadha (2005) also find that the probability of restatement is lower in companies whose boards or audit committees have an independent director with financial expertise but is not significantly related to independence alone. Karamanou and Vafeas (2005) find that the financial expertise of audit committees is associated with an increased probability of management earnings forecast updates, more informative good news forecasts, and more positive stock market reactions to management forecasts. Krishnan (2005) shows that audit committees with financial expertise are significantly less likely to be associated with incidences of internal control problems. Moreover, Krishnan and Visvanathan (2009).find that auditors charge lower fees for firms when its audit committee includes financial experts. And Chen and Zhou (2007) find audit committees with greater financial expertise were quicker to dismiss Arthur Andersen as their firm's auditor when Andersen's credibility was threatened around the Enron scandal.More recently, Krishnan et al. (2011) find the presence of directors with legal backgrounds on the audit committee is associated with higher financial reporting quality. Additional tests indicate a positive association between changes in legal expertise and changes in financial reporting quality, suggesting that legal expertise serves as a monitor rather than as a signal of financial reporting quality .

\section{3. Audit quality definition, framework and indicators}

The staff's initial thinking is that an audit quality definition, framework and related AQIs are an integrated construct. The tentative definition sets the overall scope when considering audit quality. The tentative framework developed by the staff defines the essential elements of audit quality that are candidates for measurement. The staff believes AQIs provide insight into the quality of performance related to elements of the framework. While it is possible to discuss potential AQIs without a tentative definition and framework, we believe they are helpful in ensuring that we consider possible AQIs in an organized and complete fashion. Over the years, many organizations have sought to define audit quality, with little consensus. While our initial purpose is to seek SAG member input on possible AQIs, we recognize the need to ground our discussion with the working definition of audit quality developed by the staff. For purposes of our discussion, we define audit uality as meeting investors' needs for independent and reliable audits and robust audit ommittee communications on:

a) financial statements, including related disclosures;

b) assurance about internal control; and

c) going concern warnings.

In proposing a definition of audit quality, we seek to base it on concepts that are already widely accepted, rather than trying to break new conceptual ground. We ase our working definition on a common understanding of quality used in business endeavors: "meeting customer needs." This requires that we first identify the stomer. For purposes of discussion, we have leveraged the definition of a customer stated within Statement of Financial Accounting Concepts No. 8 as, "existing and potential investors, lenders, and other creditors." 4 Note that the definition focuses on deliverables and results, rather than process or inputs. While focusing 
on process is possible (e.g., audit quality is equal to compliance with auditing standards), the staff believes it is more intuitive to define audit quality in terms of results. We base the audit committees', investors', lenders', and other creditors' needs for audit services on the scope of deliverables currently required in audits of US public companies. As a result, our definition is practical, and may not meet all investors', lenders', and other creditors' needs for audit services. We decided to include audit committee communications in the definition even though it is not a deliverable investors, lenders, or other creditors receive directly. Our logic is that audit committees advance investors' interests by overseeing external auditors, and discussions with audit committees are critical to ensuring audit quality.

\section{4. Audit quality and well-functioning markets}

Audit quality plays an essential role in maintaining an efficient market environment:

- an independent, quality audit underpins confidence in the credibility and integrity of financial statements which is essential for well-functioning markets;

- the Basel Committee on Banking Supervision has highlighted the importance of audit quality for prudential supervision and market confidence; and

- the Financial Stability Board (FSB) has emphasised the role played by external audit in supporting market confidence and contributing to financial stability.

External audits performed in accordance with high quality auditing standards can promote appropriate implementation of accounting standards by reporting entities and help ensure that their financial statements are reliable, transparent and useful to the market place, thus enhancing market confidence. Moreover, sound audits can help reinforce strong corporate governance, risk management and internal controls at firms, thus contributing to financial stability.

Auditors, shareholders, directors and regulators may be in agreement on the desirability of audit quality but each may have a different meaning of the term. The definition or measurement of audit quality has been the subject of much research, consultation and debate on an international scale. Audit is not a commodity and each audit will to some degree be tailored to address the circumstances of individual clients. Audit is not an exact science and relies on professional judgment in reaching conclusions and making decisions before expressing an opinion. Audit quality is not defined in auditing standards. Standards guide auditors on what to do in an audit and compliance with standards will indicate that an audit has been carried out to acceptable levels of quality. In the standards in use now, two specifically address quality - HKSQC 1, which addresses quality control procedures across the whole audit firm and HKSA 220, which focuses on quality control in the context of individual audit engagements. Many factors contribute to or influence the quality of audit, and chief among them are the skills and experience of the people doing the audit. Another is the rigour of the audit methodology. The balance may vary from audit to audit. In February 2008 the United Kingdom Financial Reporting Council (UKFRC), following extensive international consultation and drawing on earlier work by the auditing profession, published "The Audit Quality Framework" to help communication between auditors, audit committees, preparers, investors and other stakeholders on audit quality. This publication identified five elements of audit quality, which have generally been accepted internationally as the key influences on audit quality and have been used in further onsultation and discussion by bodies such as IOSCO. 


\section{5. Population, statistical sampling and survey period}

The study population consisted of all listed companies on the Stock Exchange Tehran. Due to the vast size of its population and the unique challenges and there is also some inconsistency among community members in relation to data Study, the following criteria for selection of statistical samples and placed they statistical sample Systematic elimination method selected. To test the hypotheses of this research, the researcher made questionnaire was used. Between financial executives listed companies in Tehran Stock Exchange has been distributed. Study period is years 2008-2012.

\section{6. Data collection and analysis}

Explanation for gathering information on literature research library method and documentary studies used to obtain information needed to process hypothesis, the information contained in the software and evaluate new company Rahavard Financial statements of listed companies in Tehran Stock Exchange by visiting the site Tehran Stock Exchange official use.

At this point, after collecting Excel was used for statistical data, and summarized the calculations required for the application SPSS version 19, compiled the research hypotheses and findings, the statistical software package the final analysis was composed. Notably Methods for Data Sectional study in the year. In the present study, three of the names of audit quality work Auditing firms, accountancy firms are examined period Hsabsy and good reputation.

The main hypothesis.

There is a significant relationship between audit quality and financial performance.

The first sub-hypothesis:

There is a significant correlation between the period of audit and financial performance.

Table 1. The first hypothesis tests.

\begin{tabular}{|c|c|c|c|c|}
\hline $\begin{array}{c}\text { Independent } \\
\text { variable }\end{array}$ & $\begin{array}{c}\text { Dependent } \\
\text { variable }\end{array}$ & $\begin{array}{c}\text { Correlation } \\
\text { coefficient }\end{array}$ & Sig & Result \\
\hline period of audit & $\begin{array}{c}\text { financial } \\
\text { performance }\end{array}$ & $0 / 732$ & $0 / 000$ & $\begin{array}{c}\text { Positive correlation } \\
\text { with } 99 \% \\
\text { confidence }\end{array}$ \\
\hline
\end{tabular}

The second sub-hypothesis:

Audit firm reputation and significant relationship between financial performance there.

Table 2. The second hypothesis tests.

\begin{tabular}{|c|c|c|c|c|}
\hline $\begin{array}{c}\text { Independent } \\
\text { variable }\end{array}$ & $\begin{array}{c}\text { Dependent } \\
\text { variable }\end{array}$ & $\begin{array}{c}\text { Correlation } \\
\text { coefficient }\end{array}$ & Sig & Result \\
\hline $\begin{array}{c}\text { Audit firm } \\
\text { reputation }\end{array}$ & $\begin{array}{c}\text { financial } \\
\text { performance }\end{array}$ & $0 / 763$ & $0 / 000$ & $\begin{array}{c}\text { Positive correlation } \\
\text { with } 99 \% \\
\text { confidence }\end{array}$ \\
\hline
\end{tabular}


The third sub-hypothesis:

Significant relationship between financial performance and audit firm experience there.

Table 3. The third hypothesis tests.

\begin{tabular}{|c|c|c|c|c|}
\hline $\begin{array}{c}\text { Independent } \\
\text { variable }\end{array}$ & $\begin{array}{c}\text { Dependent } \\
\text { variable }\end{array}$ & $\begin{array}{c}\text { Correlation } \\
\text { coefficient }\end{array}$ & Sig & Result \\
\hline $\begin{array}{c}\text { audit firm } \\
\text { experience }\end{array}$ & $\begin{array}{c}\text { financial } \\
\text { performance }\end{array}$ & $0 / 868$ & $0 / 000$ & $\begin{array}{c}\text { Positive correlation } \\
\text { with } 99 \% \\
\text { confidence }\end{array}$ \\
\hline
\end{tabular}

\section{CONCLUSION}

This study examined the relationship between audit quality and financial performance discussed and evaluated. After hypothesis testing determined that the audit quality of corporate financial performance has positive drug Arttbat entity. Major role in supporting independent audit and reporting quality financial and public interest plays. So it affects the quality of a large number of direct and indirect drivers of the main issues are considered Tdvy Gnndgan Auditing Standards is considered. Applied Literature, audit quality through Measuring compliance with the auditing standards defined. Providing auditing standards generally accepted standards Audit key role in improving audit quality and the ability to Auditors are important in the prevention and detection distortions. In addition to audit and enforce standards of care Professionals who keep the true character of the contribution of audit quality it is remarkable, competence and reputation of auditors audit process and environmental factors also impact on the quality are audited.

\section{References}

[1] Chobanian, Bakris GL, Black HR, et al., Hypertension 42 (2003) 1206-52.

[2] Chiraz Ben Ali Ce'dric Lesage, China Journal of Accounting Research 6 (2013) 21-34.

[3] Frankel R., Johnson M., Nelson K., The Accounting Review 77 (2002) 71-105.

[4] Guo R., Lev B., Zhou N., Journal of Accounting, Auditing and Finance 20 (2005) 423-459.

[5] Krishnamurthy S., Zhou J., Zhou N., Contemporary Accounting Research 23(2006) 465-490.

[6] Krishnan J., The Accounting Review 80 (2005) 649-675.

[7] Mabotuwana T., Warren J., Gaikwad R., et al, Health Care and Inform Rev Online 12 (2008) 19-24.

[8] Mitra S., Cready W. M., Journal of Accounting, Auditing \& Finance 20 (2005 ) 257-286.

[9] Pincus K., Rusbarsky M., Wong J., Journal of Accounting and Public Policy 8 (1989) 239-265. 
[10] Seok Woo Jeong, Joonhwa Rho, The International Journal of Accounting 39(2) (2004) 175-196.

[11] Thusitha Mabotuwana, Jim Warren, Journal of Biomedical Informatics (2010) 144-158.

[12] Trien L., Chizema A., Organizations \& Markets in Emerging Economies 2 (2011) $72-90$.

[13] Whisenant S., Sankaraguruswamy S., Raghunandan K., Journal of Accounting Research 41 (2003) 721-744.

[14] Yan Zhang, Jian Zhou Nan Zhou, Journal of Accounting and Public Policy 26 (2007) 300-327.

[15] Morteza Ziaee, International Letters of Social and Humanistic Sciences 9 (2014) 57-65.

[16] Mohsen Mehrara, Amin Haghnejad, Jalal Dehnavi, Fereshteh Jandaghi Meybodi, International Letters of Social and Humanistic Sciences 3 (2014) 1-19.

[17] Mohsen Mehrara, Hamid Abrishami, Mostafa Boroujli, Mahan Amin, International Letters of Social and Humanistic Sciences 11 (2013) 76-83.

[18] Mohsen Mehrara, International Letters of Social and Humanistic Sciences 9 (2013) 59-64.

[19] Mohsen Mehrara, Maysam Musai, International Letters of Social and Humanistic Sciences 8 (2013) 1-7.

[20] Mohsen Mehrara, Masoumeh zirak, International Letters of Social and Humanistic Sciences 2 (2013) 32-38. 